\title{
赤外レーザー内視鏡による胃癌の精密診断
}

\section{Detailed diagnosis on gastric cancer with infrared laser endoscopy}

\author{
三村征四郎, 一居 誠, 奥田 茂 \\ Seishiro Mimura, Makoto Ichii, Shigeru Okuda \\ 大阪府立成人病センター第 3 内科 \\ Department of Gastroenterology, The Center for Adult Diseases, Osaka
}

\begin{abstract}
Infrared laser endoscopy was devised to diagnose the depth and spread of involvement of gastric cancer. The beam of IR laser with an output of 200 to $400 \mathrm{~mW}$ at $805 \mathrm{~nm}$ wavelength was produced by a krypton dye laser. It was led through a diffuser into the light guide fiber bundle of a conventional gastrofiberscope, so that the gastric wall was illuminated uniformly. Since infrared rays are invisible to naked eye, reflected light was visualized by an IR vidicon tube on a television monitor. That made possible the realtime observation of the gastric wall illuminated by the IR laser on the TV monitor. The vessels of gastric wall were observed in positive image, because hemoglobin absorbs infrared rays considerably. ICG which was used as a routine liver function test and had a strong absorption peak at 805 $\mathrm{nm}$, was injected intravenously, and the vascular network of the deep layers was obviously enhanced.

Forty-six gastric cancer cases were examined by this method. About 10 seconds after beginning of intravenous injection of ICG $(5 \mathrm{mg} / \mathrm{kg})$, the image of vessels became markedly clear in all of cases. In a few minutes, tumor stain and pooling phenomenon were observed. The characteristic findings of IR laser endoscopy are disappearance of normal vascular network of the mucosa with thin tumor stain in mucosal cancer, thick tumor stain and pooling on the margin in submucosal cancer, thick tumor stain on the crater in advanced cancer, respectively.

In 23 out of 46 cases with gastric cancer, findings of infrared laser endoscopy were studied by referring the operated gastric specimens. Tumor stain and/or pooling phenomenon were observed along the whole margin in 11 cases, at half margin in 6 cases, and partially in 6 cases, respectively. In other 15 cases with 16 gastric cancer lesions, this method was under-
\end{abstract}


taken to decide the indication of endoscopic treatments, that is, HpD-photodynamic therapy and/or electrodiathermy.

This method is very useful to determine the indication for endoscopic treatment of gastric cancer.

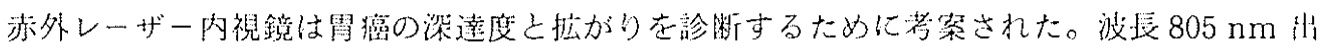
わ 200〜 $400 \mathrm{~mW}$ の赤外線はクリプトン・ダイレーザーで発振された。それはディフューザー

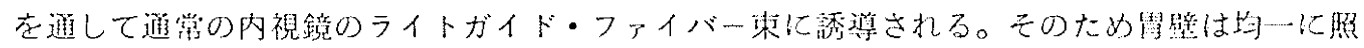

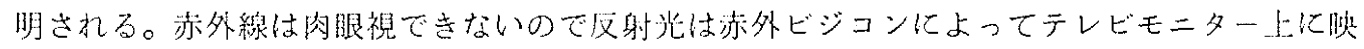
し出さ机る。それによって，赫外レーザー光で照明された㕷壁をテレビモニタートにリアル・

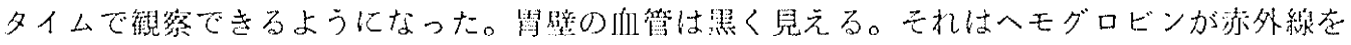

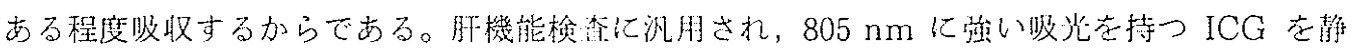
注すると，深凰の血管䔃が著明に增強された。

雪瘦46症例に本検香老行った。ICG $(5 \mathrm{mg} / \mathrm{kg})$ の静注開始から約 10 秒で，すへての症例にお

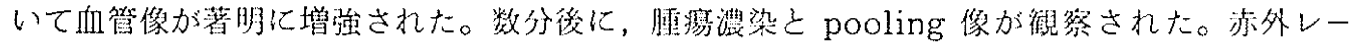

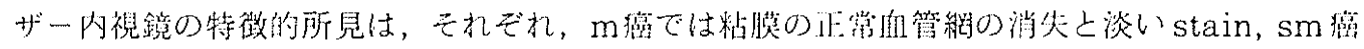

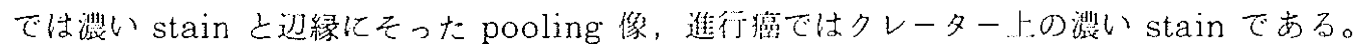

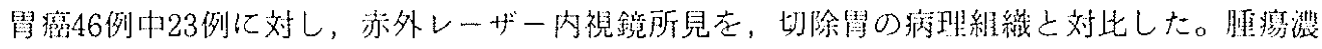

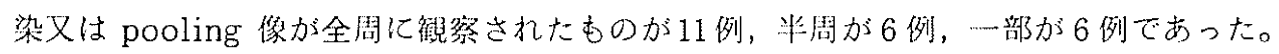

16個の帠瘦病果存有する他の15例について，本法は内視鏡下の治療の適応すなおち $\mathrm{HpD}$ 光

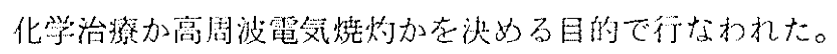

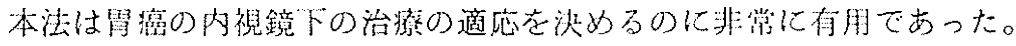

Key words : infrared laser endoscopy

laser endoscopy

early gastric cancer

depth of involvement

infrared absorption angiography

キーワーズ：浾外レーザー内視鏡

レーザー内視鏡

果期鼠癌

粱避度診㓷

浾外鼣南管造影

\section{はじめに}

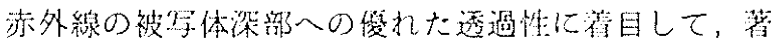
者らは赤外線胃カメラを考婪したり。乙れによって㥜壁

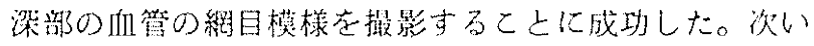
で，赫外線吸光性色紧インドシアニン・グリーン(ICG)

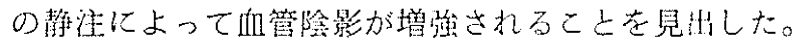
また，赤外ビジコンを用いて動的観察を四能にした。さ
らに，浾外レーザー光を照明光として利用する方法を稀

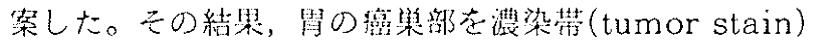
として内視鏡像に捉えることに成功した2)。

一方，舅噪の内視鏡下の治療は，エ夕ノ一ル局注法 ${ }^{3}$

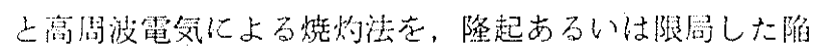
凹型早期胃㾝に対して行ってきだ)。近年，HpD光化

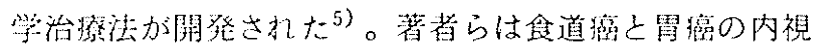




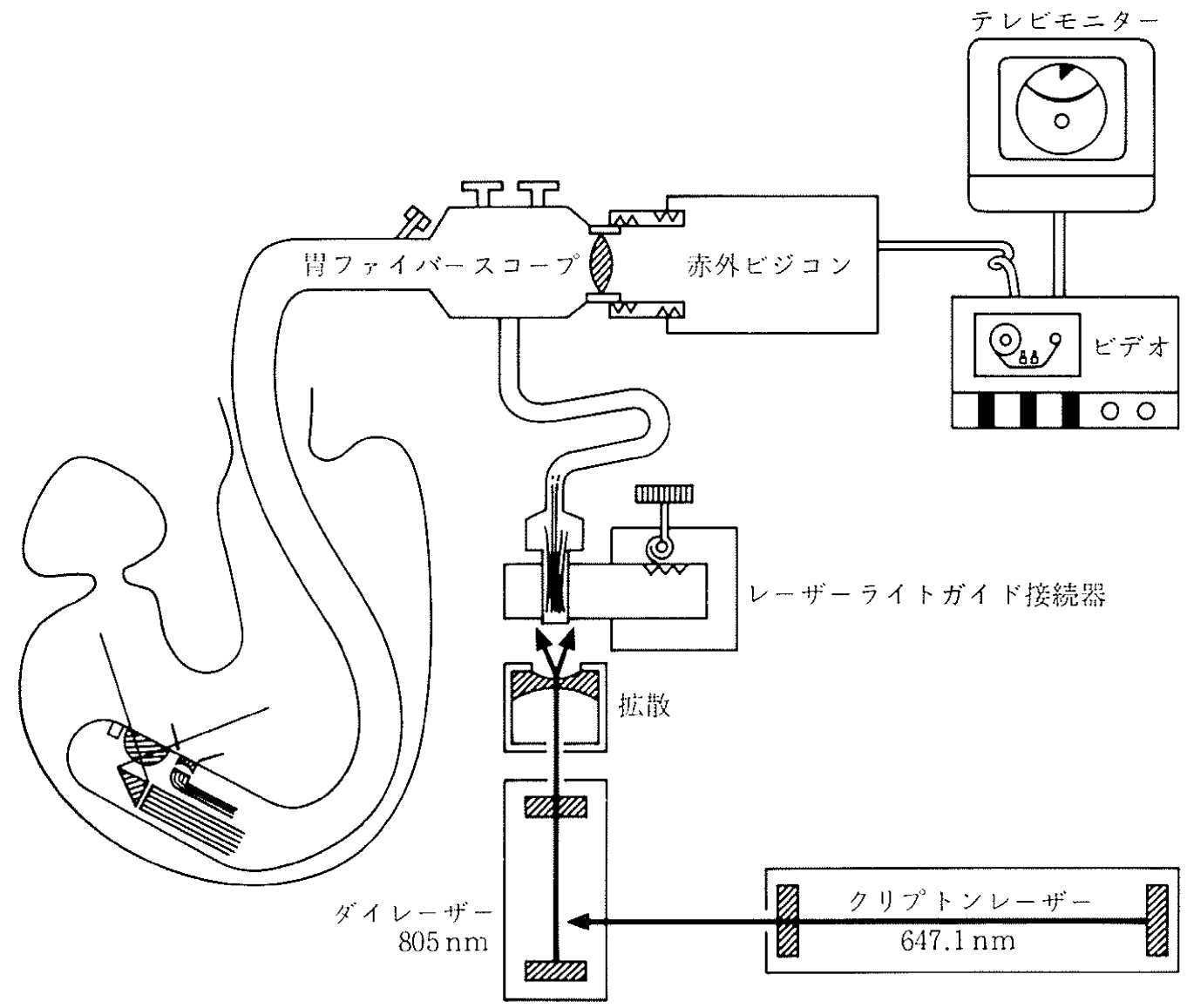

図 1 赤外レーザー内視鏡検査に用いる䒾置

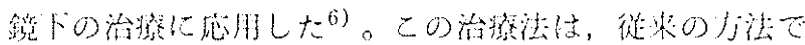

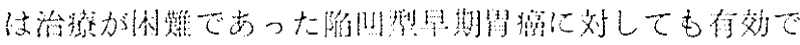
ある点加特恔である。

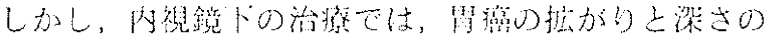

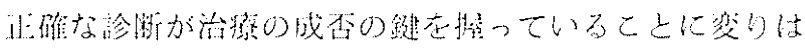
古( (2)。

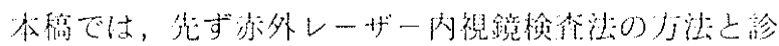

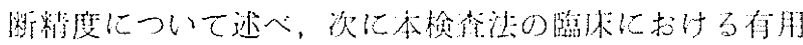

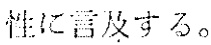

\section{目的}

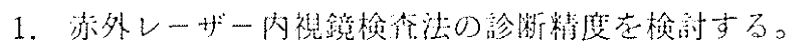

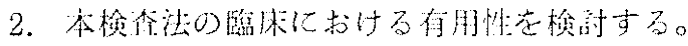

\section{対象}

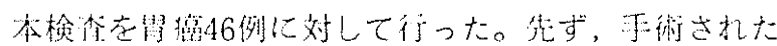

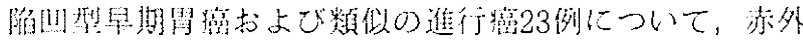

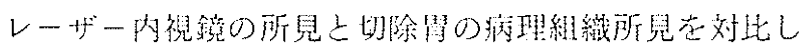

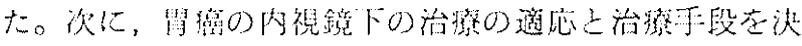

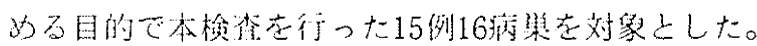

\section{方法}

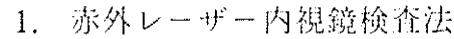

A. 装籍了。

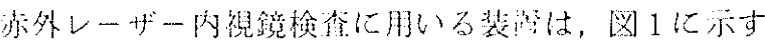

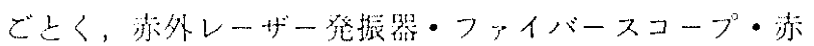
外テレビカメラ・ビデオレコーダーよテレビモニターか

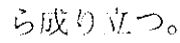

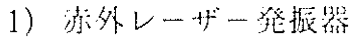

Krypton laser 励起色䍕レーザー(Spectra-Physics 社製 model 171，375）て $805 \mathrm{~nm}$ の㴒外レーザー光出 う $200 \sim 400 \mathrm{~mW}$ を発振させる。とのレーザー炎は連続 波 (continuous wave) で，ビーム佟は約 $0.5 \mathrm{~mm}$ であ る。これを付局のコンデンサー（䏴レンス）で集炎し， 焦点の後うにて光が拢散したところでライトガイド・フ テイバー束に送り达む。因のように四レンズを用いる! 法李ある。

2) 鼠ファイバースコープ

珰ファイバースコープは叮敗のもので，四には側視鋶

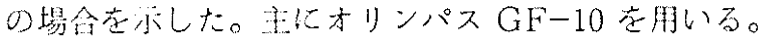

3）㴒外テレビカメラ

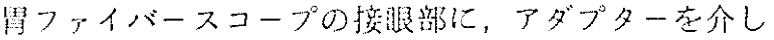




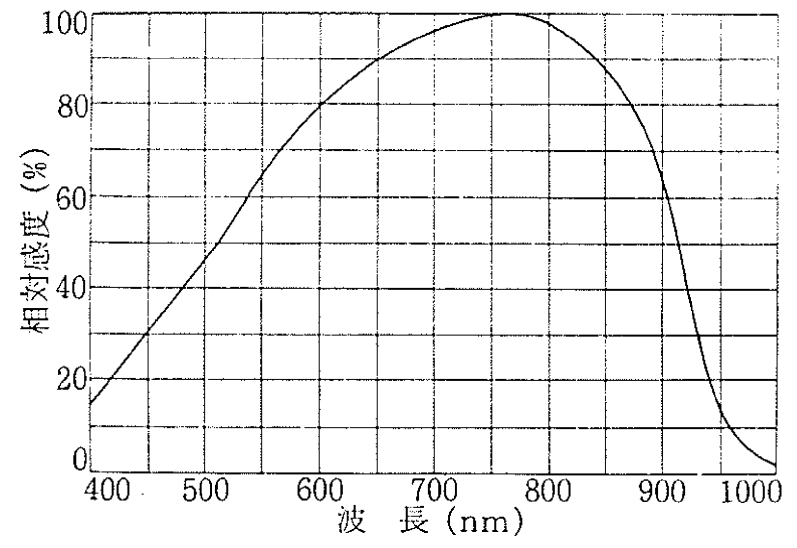

図 2 ニービコンS4119 の分光感度

て赤外テレビカメラを装賃する。現在の装留は，松下電 器社製ニュービコンS4119 索搭艘した浜松ホトニクス社 製である。このニュービコンの尔光感度は図 2 のでとく 可視全域から赤外線波長 $1,000 \mathrm{~nm}$ までである ${ }^{8)}$ 。

4) ビデオレコーダーとテレビモニター

ビデオレコーダーはソニー社製 U-matic model VO2960,テレビモニターは池上通信社裂 model PM 950 である。

B. 検些方法

1) 前処制:

一般の舅内視鏡检枯と同様に，抗コリン剂在注射し，

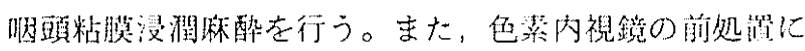
準じてプロナ一ゼ，重晁，ガスコン液京服朋させ，体位 変换を行う9)。さらに，本検雀では，テフロン針で静服 を碓保しておく。それは，榆睢中にインドシニアン・グ リーン(ICG)を静注するためである。

2) 検霜声技

盟内視鏡老経口的に插入し，琹内容液を吸引後送気し

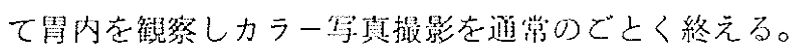
次いで赤外レーザー光钼祭に移る。琴ファイバースコー プのライトガイド・ファイバー束をXenon 球の光源装 军から外して，図10ごとくレーザーライトガイド按続 器2)に㨀し込む。また，琴ファイバースコープの按眼部 を赤外ビジコンに付ける。する上，赤外レーザー光で照 明された留壁の内視鏡像がテレビモニター上に白黒で钼 察される。同時にビデオレコーダーに録四・録音范行う。

3）ICGによる陰影の增㧧

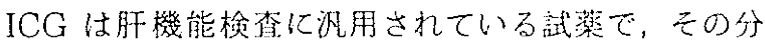
光透過率を測定してみると，図 3 のでとく，水溶液中で は $780 \mathrm{~nm}$ に，血清中では $805 \mathrm{~nm}$ に深い谷がある。と の ICG 学 $\mathrm{Rmax}$ の使用墨である $5 \mathrm{mg} / \mathrm{kg}$ 在約10秒間 で静注する10)。

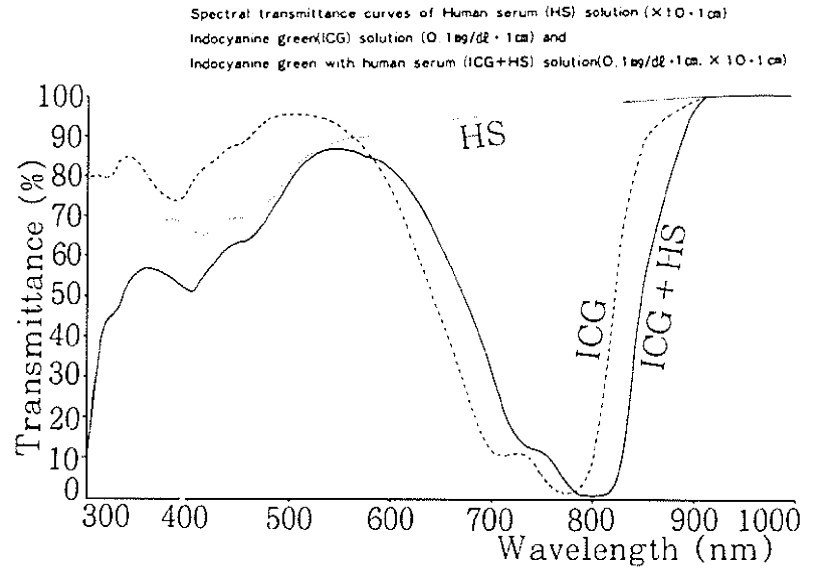

図 3 ICG の分光透過率

\section{結果}

1. 赫外レーザー内視鋅所見

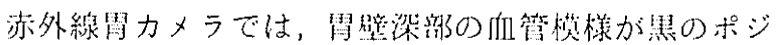

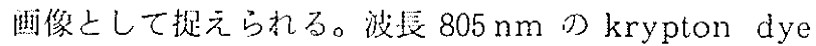
laser 光で照明し，赫外テレビカメラで揭影した盟紫の 内視鏡像においても，太心血管が樹校状に悲く見える。 そこへICGを静注するとまず太い但管除影が源くな

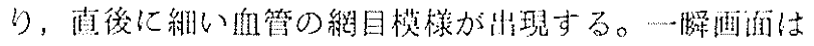

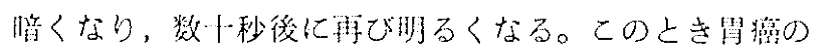
漫洞箱明に一致して tumor stain が出現する。数分後

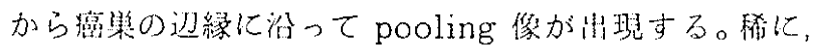
ICG 静注淔後に stain が琴われて数秒間で消退するも

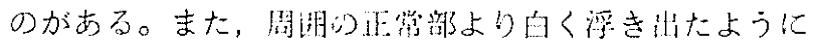
見える癌橸もある。

陷川型早期雪癌求よび頪似の進行癌における浾外レー

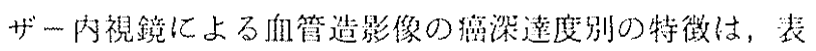
1 のどとくで，粘膜内 $(\mathrm{m})$ 虂は淡い tumor stain，粘

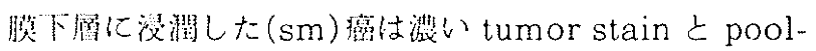
ing, 進行癌( pm以上) は crater 内の tumor stain で ある゙1。

\section{2. 診断精度}

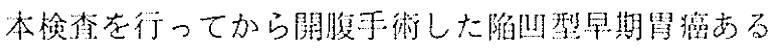
いは類似の進行癌23例について, 浾外レーザー内視鏡所

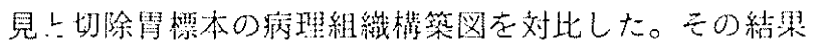

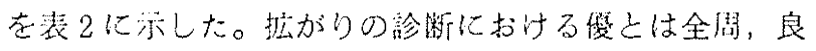

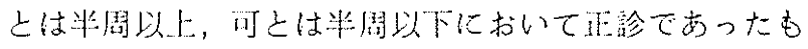
のである。僈と良を有効例とみなすと，有效摔は17/23

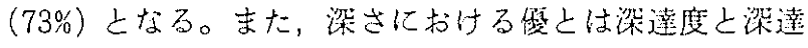
部位が正しかったもの，良とは深達度は汇しかったが，

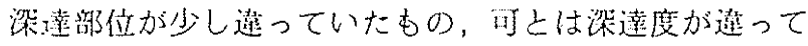
いたむのである。不问とは何ら情報が得られなかったも 
表 1 赤外レーザー内視鏡検査による、胃癌の深達度別 特徵

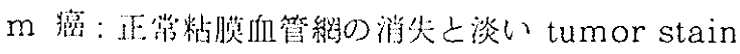
sm 癌: 涨い tumor stain 之巡緗の pooling 像 進行癌：crater内部の tumor stain
表 2 赤外レーザー内視鏡検査の診断精度 一切除胃23 例の病理組織構築図との対比一

\begin{tabular}{|c|c|c|c|c|}
\hline 評俩 & 佬 & 良 & 团 & 不四 \\
\hline 㕕がり & 11 & 6 & 6 & 0 \\
\hline 樑 さ & 10 & 8 & 4 & 1 \\
\hline
\end{tabular}

\begin{tabular}{|c|c|c|c|c|c|c|c|}
\hline \multirow{3}{*}{$\frac{\text { No. }}{1 .}$} & \multirow{3}{*}{ 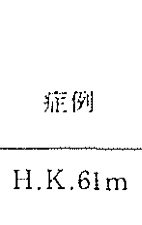 } & \multicolumn{5}{|c|}{ 表 3 赤外レーザー内視鏡所見と治療方法 } & \multirow[b]{2}{*}{ 治 桼 } \\
\hline & & 约期猚烈 & 4:检の絸摧型! & $\begin{array}{l}\text { 赫外 L- } \\
\text { stain }\end{array}$ & $\begin{array}{l}+\forall ゙-\text { 内視錇所見 } \\
\text { pooling }\end{array}$ & 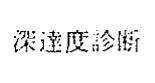 & \\
\hline & & $I+11 a$ & $\begin{array}{l}\text { well diff. } \\
\text { adeno-ca. }\end{array}$ & $H$ & - & $\mathrm{m}$ & stripping snarectomy \\
\hline 2. & M.T.48f & Ila & $\begin{array}{l}\text { well diff. } \\
\text { adeno-ca. }\end{array}$ & + & - & $m$ & stripping snarectomy \\
\hline 3. & М.T.691 & Ha & $\begin{array}{l}\text { well diff. } \\
\text { adeno-ca. }\end{array}$ & + & - & $\mathrm{m}$ & stripping snarectomy \\
\hline 4. & D.K. $77 \mathrm{~m}$ & Ila assembled & $\begin{array}{l}\text { well diff. } \\
\text { adeno-ca. }\end{array}$ & + & - & $\mathrm{m}$ & HpD-PDT \\
\hline 5. & K.K.59f & $\|a+\| b$ & $\begin{array}{l}\text { well diff. } \\
\text { adeno-ca. }\end{array}$ & + & - & $\mathrm{m}$ & HpD-PDT \\
\hline 6. & T.T.72m & IIc conv. (-) & $\begin{array}{l}\text { well diff. } \\
\text { adeno-ca. }\end{array}$ & - & - & $\mathrm{m}$ & HpD-PDT \\
\hline 7. & S.A.79m & Ilc conv. $(-)$ & $\begin{array}{l}\text { well diff. } \\
\text { adeno-ca. }\end{array}$ & + & - & $\mathrm{m}$ & HpD-PDT \\
\hline 8. & T.O.85m & Ilc conv. $(-)$ & $\begin{array}{l}\text { well diff. } \\
\text { adeno-ca. }\end{array}$ & + & - & $\mathrm{m}$ & surgery \\
\hline 9. & S.S.65m & Ilc conv. $(+)$ & $\begin{array}{l}\text { well diff. } \\
\text { adeno-ca. }\end{array}$ & + & - & $\mathrm{m}$ & $\mathrm{HpD-PDT}$ \\
\hline 10 & M.U. $68 \mathrm{~m}$ & Ilc conv. $(+)$ & $\begin{array}{l}\text { Signet-ring } \\
\text { cell ca. }\end{array}$ & H & - & $\mathrm{m}$ & HpD-PDT \\
\hline 11. & $\mathrm{~T} .0 .85 \mathrm{~m}$ & $\mathrm{Ila}+\| \mathrm{lc}$ & $\begin{array}{l}\text { well diff. } \\
\text { adeno-ca. }\end{array}$ & $H$ & + & $\mathrm{sm}$ & surgery \\
\hline 12. & S.M.59f & Ilc conv. $(-)$ & $\begin{array}{l}\text { well diff. } \\
\text { adeno-ca. }\end{array}$ & H & + & $\mathrm{sm}$ & HpD-PDT \\
\hline 13. & Y.K.70f & Ilc conv. $(+)$ & $\begin{array}{l}\text { mod. diff. } \\
\text { adeno-ca. }\end{array}$ & $H$ & + & $\mathrm{sm}$ & $\mathrm{HpD}-\mathrm{PDT}$ \\
\hline 14. & Y.T.75m & Ilc conv. $(+)$ & $\begin{array}{l}\text { well diff. } \\
\text { adeno-ca. }\end{array}$ & H & + & $\mathrm{sm}$ & $\begin{array}{l}\text { partial treatment } \\
\text { for stenosis by hot biopsy }\end{array}$ \\
\hline 15. & S.S.72f & Ilc conv. $(+)$ & $\begin{array}{l}\text { mod. diff. } \\
\text { adeno-ca. }\end{array}$ & H & + & $\mathrm{sm}$ & HpD-PDT \\
\hline 16. & I. T. $61 \mathrm{~m}$ & Ilc conv. $(+)+\mathrm{ll} b$ & $\begin{array}{l}\text { mod. diff. } \\
\text { adeno-ca. }\end{array}$ & $H$ & + & $\mathrm{sm}$ & surgery \\
\hline
\end{tabular}

のである。優を有效例とみなすと10/23(43\%)，良を加 えると 18/23(78\%) となる。

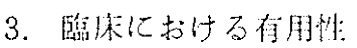

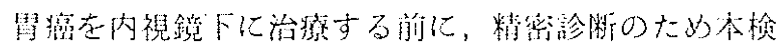

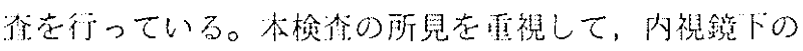

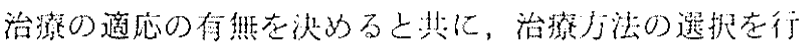

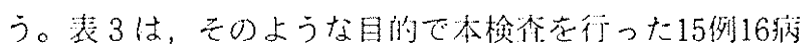

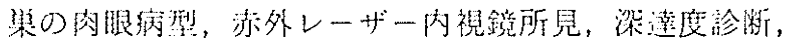
治療方法范まとめたものである。隆起性病变厂型は，本

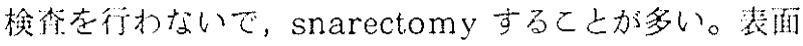
隆起犁 lla では, stripping snarectomy が選ばれる (症例 No.1，2，3）。集簿型(assembled type) Ila(症例

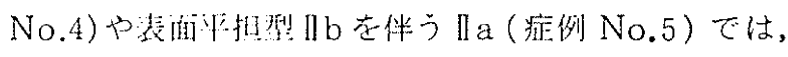

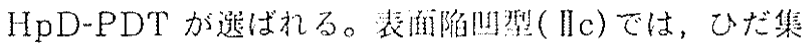
中(convergence)の有然に関わらず HpD-PDT が非ば れる(症例 No.6, 7, 9, 10,12,13,15)。症例 No.16は

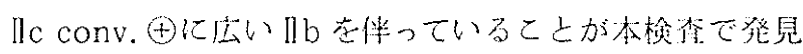
された。HpD-PDTを武みたが有所治猶が得ら机なか ったので，5箈月後㨪全摘術范行った。また，症例No. 8 上No.11は同一症例の西複癌である。いずれも広籍

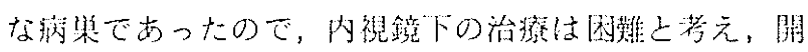
腹居術在行った。 


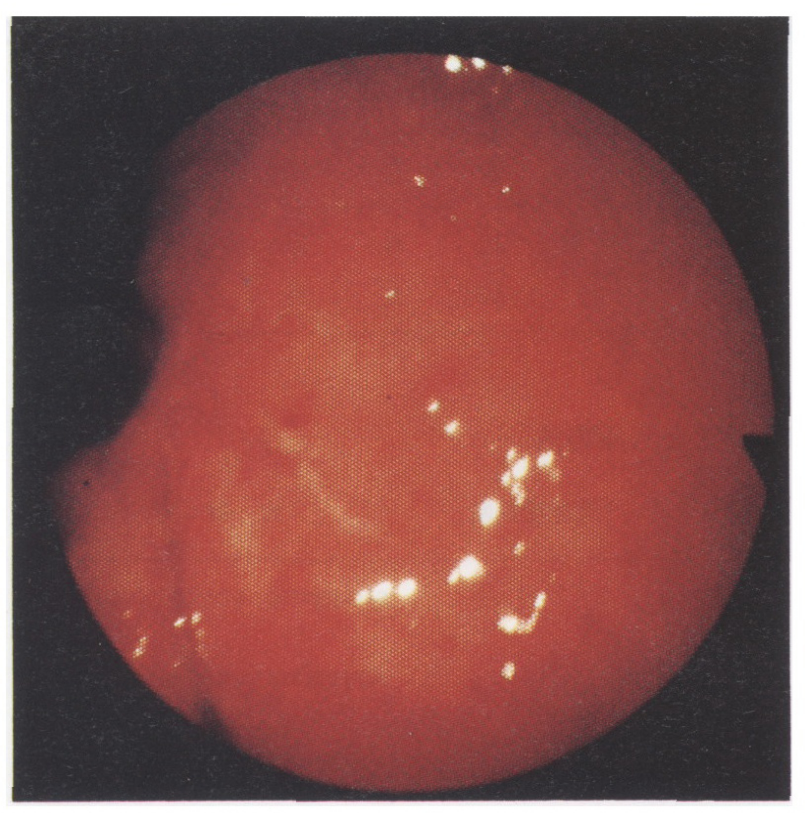

写真 1 症例 1、表面陥凹型早期胃癌、譬集中を伴う型 ( II c conv.๑)。通常内視鏡による体下部小弯の 見下ろし像。視野の左端が病巣の中心部である。 画面の中央や〉上部、退色帯の一部に癌巣は拡 がっているのであるが、その輪郭は辿れない。

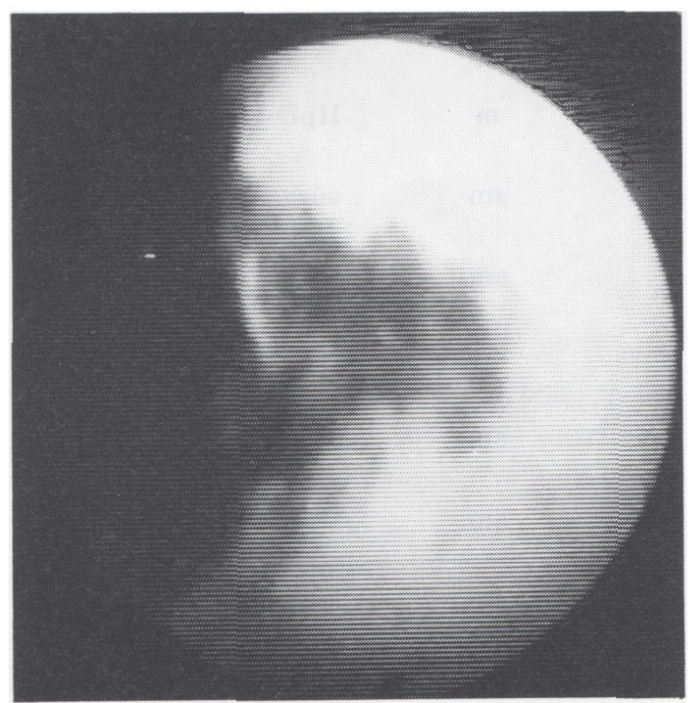

写真 2 症例 1 の赤外レーザー内視鏡像。ICG 静注後 2 分。画面中央の淡い stain が粘膜 $(\mathrm{m})$ の定型的 所見である。

\section{症例}

症例を 2 例呈示する。

1. 症例 1, I. T. 61 歳男。年齿, 全身状態, 臓器機能 などからみて手術可能である。しかし，全身の慢性湿疹 を20年来病っていて, 汎発性湿疹の形をとる。腹壁は苔 癬状湿疹であるため, 患者は内視鏡下の治療を希望した。 胃癌の病巣は, 体下部後壁にあり表面陥凹型早期胃癌

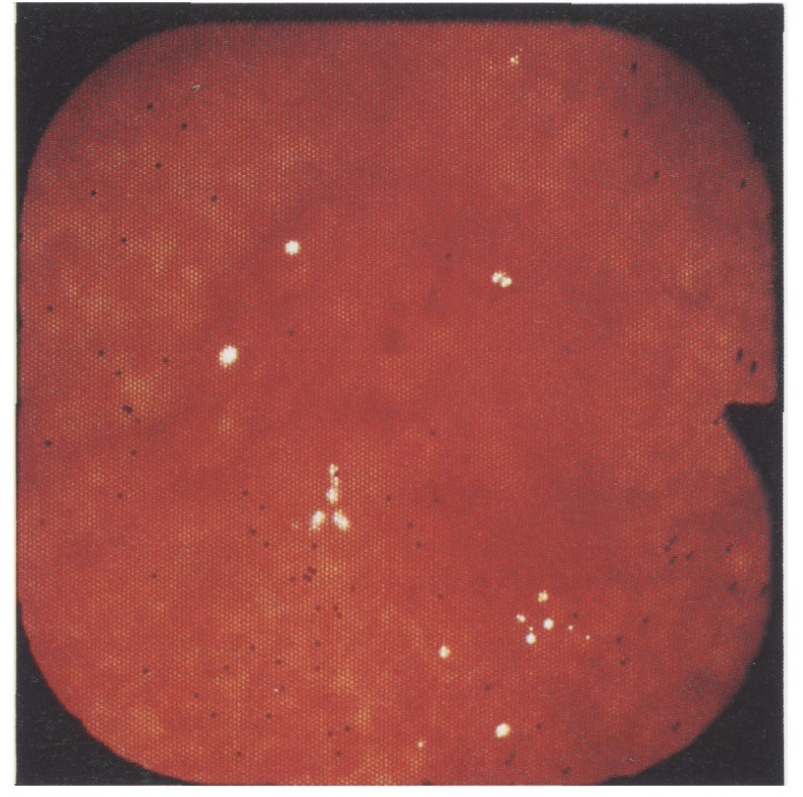

写真 3 症例 2、表面陥凹型早期胃癌、譬集中を伴わな い型 ( IIc conv. $\Theta$ ) の通常内視鏡像。画面の中 央に発赤帯として病巣が捉えられている。

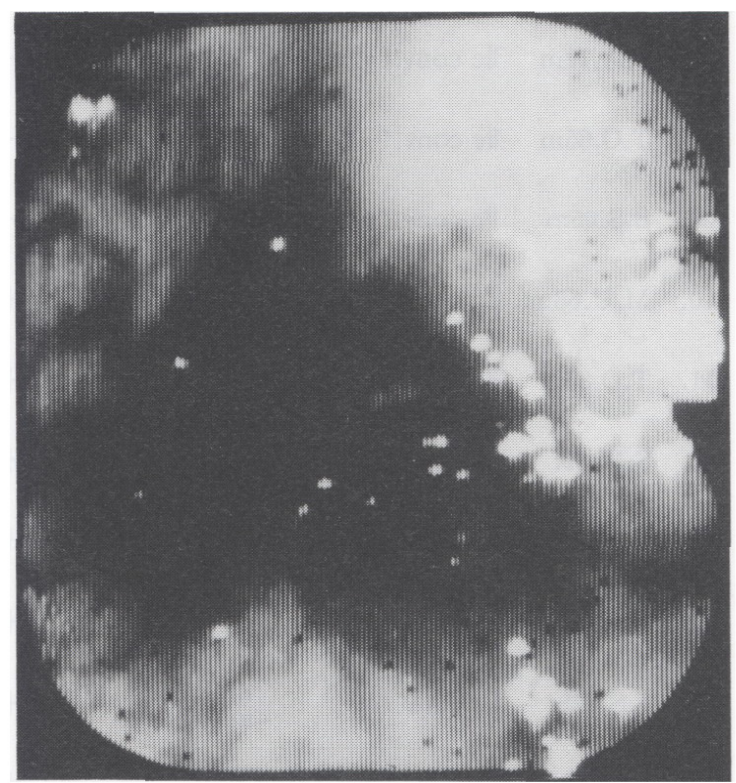

写真 4 症例 2 の赤外レーザー内視鏡像。ICG 静注後 6 分。画面中央の濃い stain が癌巣で、粘膜下に 浸潤した癌 $(\mathrm{sm})$ の定型的所兒の1つである。

( IIc)で，襞集中を伴う(convergence $\oplus)$ 。組織型は中 分化型管状腺癌であった。治療前の精密診断を目的とし て，赤外レーザー内視鏡検査を行った。写真 1 は，通常 の内視鏡写真である。胃体下部小弯を見下ろしたところ で，視野の左端に急峻な切込みの陷凹があって，後壁お よびロ側後壁寄りから譬が集中し中断している。Ilc conv. †の所見である。写真 2 は，引き続き行った赤外レーザ 一内視鏡検査のビデオの 1 コマで, ICG 静注後 2 分で ある。視野の中央に淡い stain が拡っている。その左下 


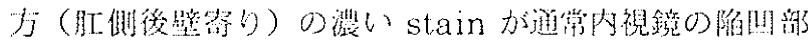

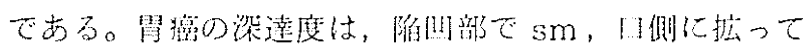

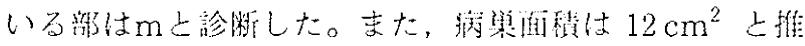

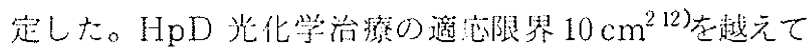

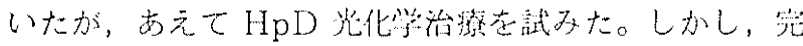

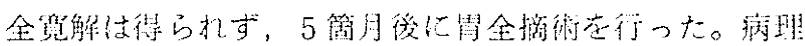

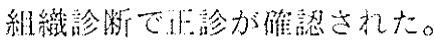

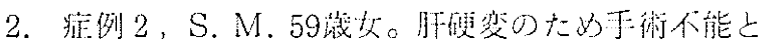

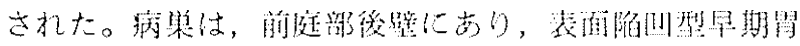

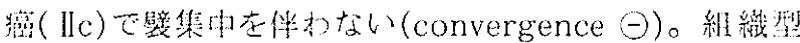
は高分化型管状腺滰であった。HpD光化受治療前の精

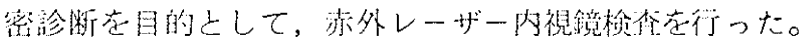

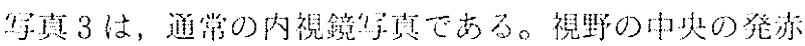

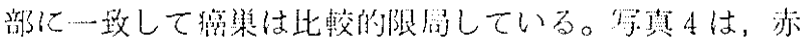
外レーザー内視鏡梌查のビデオからのスチール马具で，

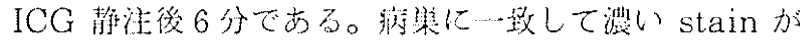
提えられている。癌深達度 $\mathrm{sm}$ 上診䉼した。本例に刘し ては $\mathrm{HpD}$ 炎化学治獠度行った。

\section{考按}

先ず，赤外線光源としてレーザー光在用いた意莪につ

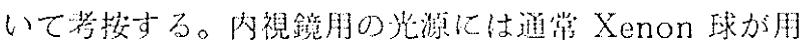

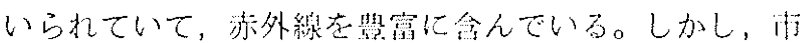
販の内視鏡用光源装湴には赤外線除士フィルターが取り 付けら㣗ている。そこで，このフィルター䒬除して， 代りに可視光除土フィルター在装期する上赫外線光源に

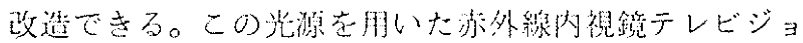

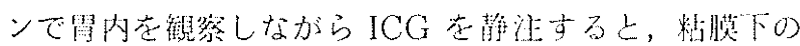

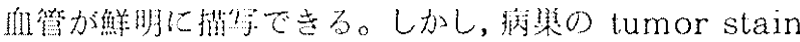

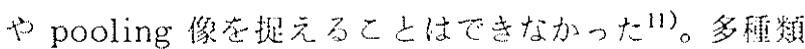

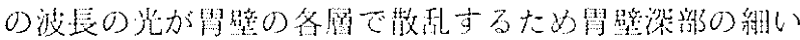

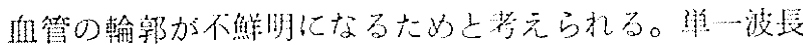
のレーザー光による高解像力の酒像によって初るて tumor stainや pooling 像が得られたのである。

次に ICGについてであるが，体朋量の $5 \mathrm{mg} / \mathrm{kg}$ は

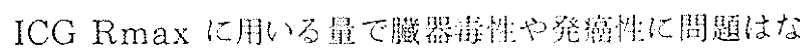
い。しかし，アレルギーによるショック例があるので，

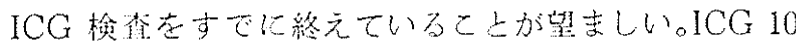
バイヤル趸 $20 \mathrm{~m}$ ! の蒸留水で澥し，テフロン針から約 10秒間で静注している。この急速注人によって，舫䑤相

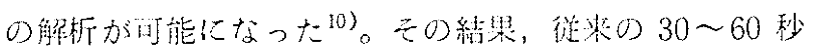
間かけた緩徐な注人では，見逃していたII a 㤠早期閒癌

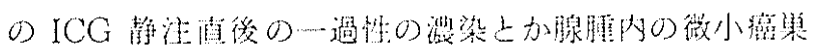
が猢胙できるようになった。

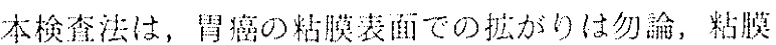

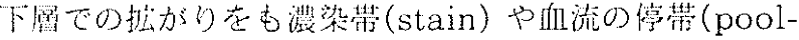
ing）上して提えることができる。また，哹笨のどの部 位加潜達しているの加内視鏡像上值接示されるので，

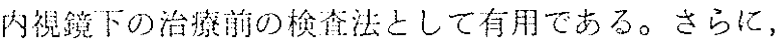

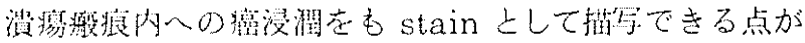
特徵である゙リ。しかし，本検查法にはいくつかの閏題点

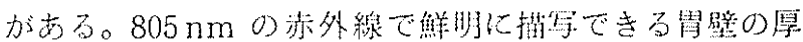
さは $5 \mathrm{~mm}$ 位上考えら㧈る1)。乙のため固有筋層 $(\mathrm{pm})$

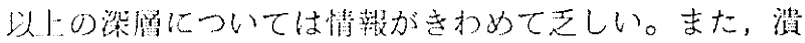

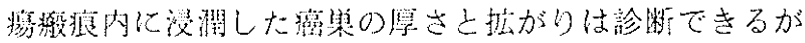

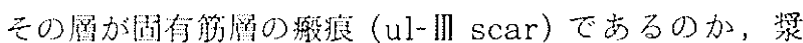

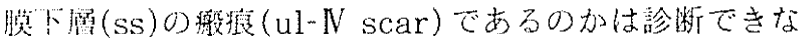

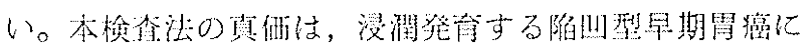

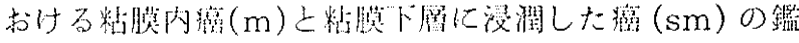
则において発摃されると言える。

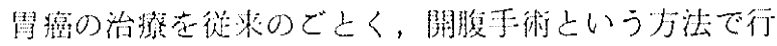

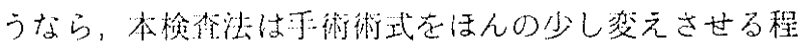

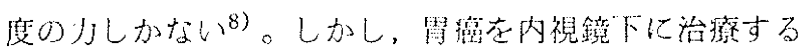

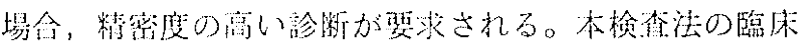
に㧍ける有网性については結果の項で詳しく述べた。ま

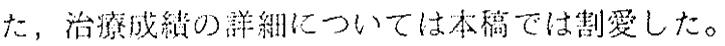

鼠後に，内視鏡下の澏治療では，初回の治療が非常に 大切である。このために，治源前の精嘧診断が重琶であ

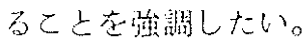

\section{結論}

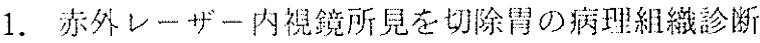

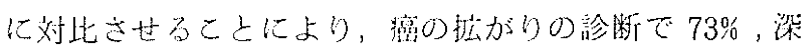

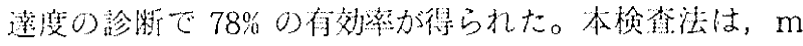

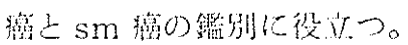

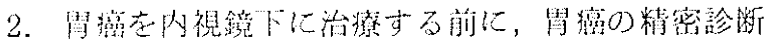

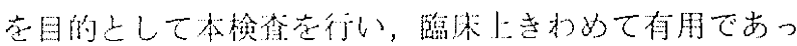
た。

\section{謝辞}

本研究は，一部厚生㜔が九研究助成金 $(62-30)$ および

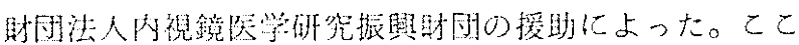
に記して即意在鈛す。

\section{文献}

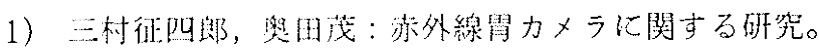
Gastroenterological Endoscopy, 21 : 511 $519,1979$.

2) Okuda, S., Otani, T., Mimura, S., et al : Application of dye laser to gastroendo- 
scopy. The 4 th congress of the international society for laser surgery. p.17-5 178, Tokyo, 1981.

3) Otani, T., Tatsuka, T., Kanamaru, K., et al : Intramural injection of ethanol under direct vision for the treatment of protuberant lesions of the stomach.

Gastroenterology 69: 123 129, 1975.

4) Imanishi, K., Otani, T., and Okuda, S., : Progress in endoscopic treatment of early gastric cancer with intramural ethanol in jection and electrodiathermy.

Recent topics of digestive endoscopy, edited by Takemoto, T. and Kawai, K., p.340 344, Excepta Medica, Amsterdam, 1987.

5) Dougherty T.J., Lawrence, G., Kaufman J.H., et al: Photoradiation in the treatment of recurrent breast carcinoma.

J. Natl. Cancer Inst., $62: 231 \sim 237,1979$.

6）三村征四郎，大谷透，今西清，他：老年者帠癌の治 療 一 局所療法 - 。Geriatric Medicine, $21: 997 \sim 1006,1983$.

7）三村嘼四郎，一居誠，今西清，他：赤外レーザー内 視鏡による胃癌の精密診粊。日本レーザー医学会誌， $7: 99 \sim 100,1987$.

8）三村征四郎，今西清，大谷透，他：赤外レーザー内

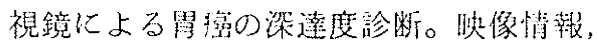
$17: 777 \sim 782,1985$.

9）井田和德，川井警市，郡大裕，他：胃内視鏡検烃に

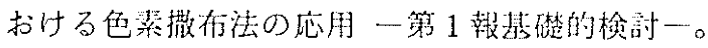
Gastroenterological Endoscopy, $14: 261 \sim 267,1972$.

10）三村征四郎，一居誠，石黑信吾，他：レーザーに上 る上部消化器癌の早期䧐断。図説臨床癌シリーズ 5 , 癌とレーザー，末多患一，池田茂人編，p.72〜81， メディカルビュー社, 1986.

11）三村征四郎，一居喴，大谷透，他：赫外レーザー内 視鏡による早期霄癌の血管造影。區休科学， $22: 549 \sim 553,1986$.

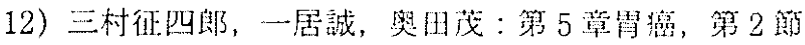
光線为学的レーザー。レーザー蕾懪治療マニュアル， 早田䟤博監修, p.124〜135, サイェンスフォーラム， 乘京, 1986 . 